\title{
Ethnography and Ethno-music of Babukusu Traditional Male Circumcision; Messaging, Symbolism and Rationale
}

\author{
Mellitus Wanyama ${ }^{1}$, Omar Egesah ${ }^{2, *}$ \\ ${ }^{1}$ Department of Literature, Theater and Film Studies, Moi University Choir \\ ${ }^{2}$ Department of Anthropology and Human Ecology at Moi University, Kenya \\ *Corresponding Author: omagesa@gmail.com
}

Copyright $@ 2015$ Horizon Research Publishing All rights reserved.

\begin{abstract}
In societies where male circumcision is practiced in Eastern and Southern Africa, circumcision is considered as a rite of passage into manhood, Columbia Encyclopaedia $^{[1]}$. In Sub-Saharan Africa, about two-thirds of men circumcise, while in Kenya male circumcision is practiced by many communities including $84 \%$ of Kenyan men, G.O.K Kenya ${ }^{[2]}$. Among Babukusu of western Kenya, traditional male circumcision entails three stages: preparation to circumcise, the actual circumcision and postcircumcision rites. These stages are engrossed by elaborate detail of ritual and ceremony that is laden with messaging, symbolism and rationale especially through music. Inevitable gradual changes in the form, content, practice and performance of Babukusu male circumcision have emasculated the erstwhile structural and functional features of the practice. It is arguable that currently its function hardly goes beyond a mark of cultural identity, Wanyama ${ }^{[3]}$. However, most messages expressed, especially in the music performed in the ceremony and the initiation package, are still relevant in modern times because themes therein are current and topical, for instance: sensitization on HIV and AIDS, and perpetuation of morals (ibid). This paper explains by means of detailed ethnography and ethno-music the significance of messages communicated during Babukusu male circumcision practice. Two questions answered by this paper are: What is the message passed through ethnographic initiation rites and through music and performance? Why are initiation and music messages that epitomize Babukusu male circumcision such important to the practice and life of Babukusu as a community? The paper assumes that the male circumcision practice of Babukusu is an avenue for moralistic and life messaging not to the initiate alone but to the wider community. This messaging is communicated through two channels, first through the initiation packages passed to the boy and two through music that characteristically embodies the importance of male circumcision from its mythical origin. In this study, data is derived from two sources; first from ethnography of Babukusu male circumcision and second
\end{abstract}

from circumcision ethno-music. Both sources of data provide a fusion of qualitative information that forms the basis of arguing this paper. At each of the three phases that mark Babukusu male circumcision, ethnography and ethnomusic carry symbolic messages that initiate the boy into adulthood and also that concern and inform the community about topical issues that affect the group and the rest of the world. They also convey important life messages about Babukusu and their values, morals, beliefs and lifestyles. The significance and importance of this traditional rite is captured through this rich ethnography and ethno-music and to understand the importance of the practice, we explore overt and covert symbolic meanings in circumcision messages.

Keywords Male Circumcision, Ethnography, Ethnomusic, Symbolic Messaging, Kenya

\section{Introduction}

Male circumcision is typically done as a rite of passage into manhood in many Sub-Sahara Africa communities including Babukusu of western Kenya. Across societies, the initiation processes follow a particular sequence though which initiates follow; removal from society; seclusion; the circumcision cut; reintegration back into community as a changed adult distinguishable from child and woman. According to UNAIDS/CAPRISA ${ }^{[4]}$ modernity factors including Christianity and colonialism have over time shaped circumcision in most African societies, although the practice still serves strong and meaningful messages to the initiate and to society. According to Marck ${ }^{[5]}$, in groups that circumcise the way Babukusu do, adolescent rites of passage for "initiation", are common and typological. While studies by $\operatorname{Marck}^{[5]}$, Van Gennep ${ }^{[6]}$ and Wagner ${ }^{[7]}$ previously point to similarities of male rites of initiation across unrelated cultures, there seem to be concurrency 
about phasing circumcision in three stages. The first phase consists of preparatory observances by the candidates and leads up to the actual circumcision cut. The second phase involves initiates spending life in the seclusion hut, referred to by Babukusu as; mwirumbi; where they stay while their wounds heal and where they are inculcated with both practical and theoretical life knowledge. What forms the content of the messages passed to the initiates and how they are conveyed, is the focus of this paper. The third phase, is marked by the 'feast of coming out of the hut of seclusion'; $k h u k h w a l u k a$, and embraces a series of rites and festivities that are cardinal and symbolic to transition into adulthood.

Babukusu practice both traditional and clinical circumcision. Two different techniques of traditional circumcision manifest, both procedures performed by a traditionally trained male circumciser. Traditional male circumcision is performed outdoor, outside the boy's parents' house and it is done early in the morning. In the most common procedure, the circumciser pulls both outer and inner foreskin of the penis and by clip of both between the thumbnail and the first finger, they make the cut. In the second procedure, which is relatively slower the circumciser pulls the outer foreskin and by the same means makes the cut, and immediately slits the inner foreskin and graces with the special double edged circumcision blade; lukembe round the glans of the penis. Both operations are preceded by a helper who dusts the foreskins with a special brick or sand baked dust referred to as; litukhuulu for firm and precise grip of the inner and outer foreskins in readiness for the cut. Babukusu also practice clinical circumcision which is conducted by a biomedical trained male clinician as an outpatient practice.

This paper presents ethnography of Babukusu circumcision dwelling on the messages passed to the initiates during the three phases in the circumcision process, and their meaning. The paper argues that circumcision process outcome is to induct moralistic, normative and value laden messages and skills into the new male adult as prescribed by Babukusu cultural expectations. The objective of this paper thus, is to describe and analyse by means of detailed ethnography and ethno-music the meaning, interpretation and rationale behind circumcision messages. The authors unequivocally posit that male circumcision practice of Babukusu is avenue by which society transfers important messages systematically targeting a generation for future productive and reproductive roles and also enlightening the larger community over prevailing life challenges. Amongst Babukusu, these vital messages are passed as lesson packages for initiating newly circumcised boys and also they are conveyed through special music that typically embody importance of male circumcision, carrying this significance on from its mythical origin.

\section{Conceptual Framework}

Ethnography is a methodological strategy used to provide descriptions of human societies, which as a methodology does not prescribe any particular method (e.g. observation, interview, questionnaire), but instead prescribes the nature of the study i.e. to holistically describe people through writing, Hammersley ${ }^{[8]}$. McCall and Simmons ${ }^{[9]}$, argue that ethnographic descriptions are analytical and primarily they are an empirical application and modification of scientific theory. Clifford Geertz ${ }^{[10]}$ in his discussion of "thick description" argues that ethnographers test theories in the very process of using them. Sorre ${ }^{[11]}$, argues that ethnography develops theory through the study of critical cases and this is achieved through study of cases or communities by grounded theorizing where induction, deduction and verification come to play and validates argument made earlier by Levi-Strauss ${ }^{[12]}$, Znanieki ${ }^{[13]}$, for analytic interpretation in which induction, hypothesizing and deduction apply. This posits ethnography as both theory and methodological design. Ethnographers stress that we move within social worlds, and that to understand the behaviour, values and meanings of any given individual or group with respect to circumcision for this matter, we must take into account the cultural context. In this respect, ethnography pays attention to the sometimes minute everyday detail of individual lives within wider social structures. This is why this paper presents a phased ethnographic detail of a phenomenon; male circumcision, which is optimal in determining the transformation of behavior and experiences of individuals within a wider cultural expectation. Thus, the object of ethnographic approach here is to explore at depth the hidden meaning of circumcision messages as held in the minds of Babukusu people, and how the meanings of these covert messages are employed in social interaction and experiences at around circumcision and for use by generations in the future. Ethnography was employed in this paper, to combine the emic view of an insider (first author) with the etic view of an outsider (second author) to describe the circumcision social setting, meaning and rationale. As the reader realizes, resulting is deep description which is fuller than that of ordinary outsider, and broader and less culture-bound than that of ordinary insider.

\section{Method}

\subsection{Study Population}

Babukusu are amongst a series of circumcising Bantu groups along the southern portions of the Kenya-Uganda border. The immediate cultural-linguistic group of which they are a part is contiguous with Bantu and Nilotic groups to the east which circumcise (Bagisu, Sabaot and Nandi) and with Nilotic groups to the south (Luo) and north (Teso) and Bantu groups to the west (Soga) which do not. Babukusu are Bantu-speaking people of western Kenya and 
they comprise more than one hundred clans, which share common backgrounds and customs, including male circumcision, strongly kin-based social networks governed traditionally by their lineage and clan elders, Osog ${ }^{[14]}$, Were $^{[15]}$, Makila ${ }^{[16]}$, Wandibba ${ }^{[17]}$. Babukusu inhabit Bungoma County in western Kenya, occupying territory on $491 \mathrm{~km}^{2}$, with an estimated population of 42,387,216 $21,070,003$ males and 21,317,213 females. Bungoma is characterized by low incomes, high child mortality and dependency ratio. Approximately 56\% Babukusu fall below the poverty line and causes of poverty in Bungoma County vary from HIV/AIDs, unemployment, squatter/landlessness, to illiteracy. Contraceptive prevalence and use in Bungoma is at $45 \%$, with $44 \%$ births delivered at home. Out of the total number of women of reproductive age who die, $21 \%$ are as a result of pregnancy related causes. According to the Kenya development indicators 2012, Bungoma records 97.0 infant deaths per 1000 live births, and the $<5$ mortality rate is $126 / 1000$ with a total fertility rate of 7.6 while the HIV prevalence rate is $20-30 \%$ in the general population, G.O.K ${ }^{[18,19,20,21]}$. Male circumcision is universal and obligatory among Babukusu. Most young men are circumcised by a traditional surgeon, but increasingly families are turning to Western-style clinical circumcision, Bailey and Egesah ${ }^{[22]}$, Egesah ${ }^{[23]}$.

\subsection{Data Collection}

The study developed data from populations in two subCounties of Bungoma County in western Kenya; Kanduyi and Bumula. Participants in this study were recruited by a two stage cluster sampling method. In the two sub-Counties 75 households were selected randomly in the 15 administrative units (locations). Two to three months prior to the circumcision month of August researchers enquired by survey at each sampled household if there was a boy present who would circumcise during the August 2004 circumcision season.

Both ethnography and ethnomusicology provide data sources for this paper. In this study, 1100 young men to be circumcised in August, 2004 were identified and from this number 1007 boys were traced back and interviewed after circumcision. In addition, we directly observed 24 circumcisions from a subset of the 1007 boys - 12 medical and 12- traditional circumcisions. Most of the ethnographic information on Babukusu male circumcision were drawn from the rural set up contexts within which circumcisions took place using direct observations and recording of events surrounding the circumcisions and from in-depth interviews and focus group discussions (FGDs) with parents of the boys who circumcised. Twenty one traditional and 20 medical practitioners were interviewed to assess their experience with the procedure, their levels of training, their experience with dealing with circumcision complications, and the amount of money they charged for the procedure. In-depth interviews generated information used in this paper to understand the significance and meaning of male circumcision amongst Babukusu. Sixteen (16) male and 16 female parents of the circumcised boys were interviewed. Stratification was made to reach 16 parents each of boys circumcised both traditionally and clinically. The parents were systematically selected in a stratified random manner from each administrative location of the two Bungoma subCounties (Kanduyi and Bumula) to reach a total of 32 consenting respondents. Focused group discussions (FGDs) were performed with male and female Babukusu adults to obtain background information on variation in circumcision practices and beliefs and attitudes about circumcision done traditionally and in medical settings. Twenty one (21) FGDs were conducted - 14 in rural areas and 7 in urban Bungoma. Ten FGDs were with females and 11 with males. Groups were divided into the following age categories: $50+$ years, 25-45 years, and 15-21 years. The latter group consisted of recently circumcised young men and each group consisted of 7-12 consenting Babukusu participants. The primary purposes of in-depth interviews and focus group discussions were, first, to explore how Babukusu talk and narrate about and how they view male circumcision. Second, was to narrate and evidence detailed descriptions of the process, meanings of circumcision messaging and related covert symbolic interpretations. The qualitative information collected during in-depth interviews, observations and focus group discussions provided important ethnographic information that we use to write this paper. The interview and FGD scripts were developed with two Babukusu male and two female research assistants. Data were generated over six months, to capture activities, processes, experiences and significances manifesting during the three Babukusu circumcision phases; pre-circumcision; circumcision; and post-circumcision phases. The research protocols were approved by the Moi University Institutional Research and Ethics Committee (IREC).

\subsection{Data Analysis}

Qualitative data were recorded on tape, transcribed in expanded field notes and keyed in MS WORD. The files were transferred to the program QSR Nudist for thematic and content analysis presented here in description, narrative and quotes. Pictures and memory recall were employed to register key disguised and non-disguised observations of events. Meanings and symbolic interpretations of key circumcision messages and their rationale were offered both by the informants and by interpretations by researchers, thus offering the weight and advantage of both emic and etic perspectives to the results.

\section{Results}

\subsection{Sociodemographic Characteristics of Respondents}

Mean age of boys circumcised medically was 13.6 years (range 5-21 years) and those done traditionally were 
slightly older averaging 14.6 years (range 5-20 years). Boys circumcised medically had 5.4 years in school while those circumcised traditionally had 5.6 years in school. The boys were overly Christian and especially Catholic and Protestant. Eighty seven percent $(87 \%)$ of boys circumcised traditionally resided in rural Bungoma County in western Kenya, while only $24 \%$ of medically circumcised boys lived in the rural. Most of the ethnographic information depicting Babukusu male circumcision was drawn from the rural set up contexts within which circumcisions took place. Twenty-one (21) traditional and 20 medical practitioners were interviewed to assess their experience with the procedure. Not surprising, the level of education of the medical practitioners was higher than that of the traditional circumcisers (15.4 years versus 6.8 years). The traditional circumcisers had performed more circumcisions over the last two years than medical circumcisers. None of the traditional circumcisers (versus three of the medical circumcisers) had performed fewer than 10 circumcisions, while 9 (versus 5) had performed more than 100 circumcisions, indicating vast experience. In-depth interview respondents were parents aged between 30-40 years and parents who had clinically circumcised their boys tended to be relatively younger than those who had traditionally circumcised boys. Apart from 4 cases $(n=32)$ who were extended family, all respondents were biological parents to the circumcising boys. All in-depth respondents were married people who lived with 6 (mode) children in their households. On average, each household had one boy circumcised during the year 2004 (mean =1). Parents of clinically circumcised boys had a relatively higher education than those with traditionally circumcised boys. The parents were farmers, unemployed or in temporary or low income employment. There was no marked distinction between the occupation of parents of boys who circumcised either traditionally or clinically. Likewise, there were no differences in religious affiliation of parents of traditionally circumcised and those of clinically circumcised boys and even between the boys and the parents. Focus group discussions were performed with male and female Babukusu adults. Ten FGDs were with females and 11 with males. As indicated earlier, groups were divided by: $50+$ years, 25-45 years, and 15-21 years. Ethnographic and ethno-music details about Babukusu male circumcisions were thus developed from various sources and from respondents with varied socio-biological characteristics.

\subsection{Ethnography and Ethno-music of Babukusu Circumcision}

\section{Babukusu circumcision myth}

The myth traces the origin to the heroics of one ancestor named Mango. As a young man Mango was very brave and daring. At Mwiala there lived a notorious serpent called; Khururwe-Yabebe which used to devour beasts and human beings that came within the proximity of its lair. News come round that Mango's son called Malaba had also been killed! Mango was so enraged that he swore to kill the murderous monster single-handed, which he did to the disbelief of the entire community and the Barwa (Kalenjin) neighbours; who practiced male circumcision. Barwa people laughed at Mango derisively and said:

"Mango, if you kill that serpent we will circumcise you and give you one of our daughters for a bride, for you shall have proven yourself an indomitable warrior, whose honor should be circumcision" Omubukusu.

At that time Babukusu had no systematic circumcision compared to Barwa. Mango killed the serpent and took up the bravery to be circumcised. His unprecedented acceptance of circumcision, as the crowning achievement of a brave warrior was consequently destined to have a profound impact on the psychology and culture of Babukusu as a group. So Mango agreed to be circumcised, and when he was being led to the circumcision ground his aging mother burst into tears and cried:

"Wooeii, wooeii! My only son. Ahaaa, hooh, Mango did I not tell you that this circumcision is painful? You have chosen it yourself. There you are!" Sifuna.

Babukusu are said to have turned these fateful words of Mango's mother into a song, thereby, composing the now famous; 'sioyaye' (revered song sang to the boy just before they circumcise) chant which is sung when the initiate is being returned from the mudding place; sietosi to the circumcision podium for the eventful cut.

\section{Sioyaye song:}

(I) Lubukusu (Babukusu language) version

\section{Soloist \& response}

i. $\quad$ Ewe ewe ewe musindewe- hoo o

ii. $\quad$ Ewe musindewe-ho o

iii. Ewe musindewe-hoo oo

iv. Ewe ewe ewe khwarakho- hoo o

v. Esiboyo- ho o

vi. Sye bakhale-hoo oo

vii. Omusinde oteremaka acha ebunyolo- ha ho

viii. Acha ebunyolo- haa ho

ix. Acha ebunyolo- haa ho oo

x. $\quad$ Ewe ewe ewe sye bakhale- hoo o

xi. Oh siboyo-ho o

xii. Sye bakhale-hoo oo

xiii. Omusinde oteremaka acha ebunyolo- haa ho

xiv. Acha ebunyolo- ha ho

xv. Acha ebunyolo- ha hoo

xvi. Ewe ewe ewe kumwana we-hoo ho

xvii. We kumwana we-hoo o

xviii. Ese ekhubolela-hoo oo

xix. Omusinde oteremaka acha ebunyolo- haa ho

xx. Acha ebunyolo- ha ho

xxi. Acha ebunyolo- ha hoo

(II) English translation 


\section{Soloist \& response}

\begin{tabular}{|c|c|}
\hline$i$. & You, you, you, the uninitiated one- hoo o \\
\hline$i i$. & You the uninitiated one- ho o \\
\hline iii. & You the uninitiated one- hoo oo \\
\hline$i v$. & You, you, you, we have started-hoo o \\
\hline$v$. & This song- ho o \\
\hline$v i$. & The one of our forefathers- hoo oo \\
\hline vii. & The initiate who fears should go to Luo-land-haa ho \\
\hline viii. & Go to Luo land-ha ho \\
\hline$i x$. & Go to Luo land-ha hoo \\
\hline$x$. & You, you, you, the song of our forefathers- hoo o \\
\hline$x i$. & Oh this song- ho o \\
\hline xii. & Of our fore fathers- hoo oo \\
\hline xiii. & $\begin{array}{l}\text { The uncircumcised one who fears the knife should go to } \\
\text { Luo-land-haa ho }\end{array}$ \\
\hline xiv. & Should go to Luo-land-ha ho \\
\hline$x v$ & Should go to Luo-land-ha hoo \\
\hline$x v i$. & You, you, you, child-hoo ho \\
\hline xvii. & You child- ho ho \\
\hline cviii. & I tell you- ho oo \\
\hline$x i x$. & $\begin{array}{l}\text { The uncircumcised one who fears the knife should go to } \\
\text { Luo-land-haa ho }\end{array}$ \\
\hline$x x$. & He should go to Luo-land-ha ho \\
\hline$x x i$. & He should go to Luo-land-ha oo \\
\hline
\end{tabular}

As mentioned, sioyaye, a special Babukusu circumcision song is regarded as a sacred song, meant only for this special occasion. The song reminds the boy about the weight of circumcision; embalu and to encourage him to face it without fear. The song is partly recited above, but its interpretation means the following:

"The Leopard which scratches hard is waiting in hiding to pounce on you. Our age-old circumcision tradition should remain with us. It was handed down to us by Mango of Mwiala. A cowardly, uncircumcised boy should take refuge in Luo country (where circumcision is traditionally not practiced). When the knife comes near the end, it hurts. If you, the uncircumcised boy is unprepared for the knife, you better give up now before it is too late" Ringo.

\section{Pre-circumcision ceremonies and their meanings}

Pre-circumcision ceremonies that mark Babukusu circumcisions have their meanings and significances. Khuchukhila is the ceremony that signals intent and commitment to circumcise. It sets off the circumcision process officially and this happens two days to circumcision day. It signals commitment of the initiate to be circumcised as described here:

Case narrative by researcher: here, and on this morning, once the boy in consultation with the family has shown interest to circumcise, the father makes a small depression in the ground outside his main house. He then takes a small pot; esachi containing fermented and fried maize flour; kamalwa kamakhalange and puts it inside that depression. The pot is decorated with star grass; lukhafwa. The star grass symbolizes prosperity, perpetuation and tenacity, amongst Babukusu. Then the boy is given another small pot and is escorted by an already circumcised man to the river to fetch water. The boy carries that pot on the shoulder and is not to greet anybody on the way to and from the river, neither should he look back. On arrival back home and at the spot where esachi is placed, the boy pours the water he has fetched into the pot on the ground containing kamalwa kamakhalange. Once this is done, the boy is handed the circumcision bells; chinyimba that he starts jingling. As he jingles the bells the special Babukusu traditional circumcision song; sioyaye is echoed by the elder (grandfather), who joins the gathering of people present to sing along as the boy trots around the pot. The grandfather, father and elders speak cautionary words to the boy to provoke the boy either surrender, or dare go ahead to face the circumcision knife; lukembe. Further to this, the mother to the boy ululates, and the boy is led away to inform and invite his relatives and especially his maternal uncles whom he must invite last on the eve of his circumcision day.

Prior to, but soon enough to the date of circumcision the boy goes around with a team of escorts guided by elder brothers or cousins and villagers to invite neighbours and close relatives of interest to this traditional rite. Close kin within reach are invited one by one by the team singing and escorting the boy jingling chinyimba. A few (about five) selected people who were circumcised the same year and even the same circumcision period together with the father of the initiate referred to as; bakoki are also reached and invited. This special group is reached by the party a day or so to the circumcision date and they are by this means invited to attend the circumcision starting from the eve of circumcision. Lastly, the boy invites his maternal uncle where he is rewarded by cattle; ekhafu specially referred to as; likhoni. Traditionally, the uncle slaughtered ekhafu and the nephew to the boy carried the meet back to the boy's home on the eve of circumcision. On occasions today, this animal is given alive to the boy to take it with him to his home where it is either slaughtered for feast on the eve of circumcision or kept to breed. At the uncle's place, the boy is instilled with courage to face the circumcision and emulate the uncle's/mother's clan. Cowardice during circumcision is commonly blamed to the maternal lineage, thus it is the duty of the maternal uncle to exonerate maternal kin from this curse in advance, by severely warning and even spanking the boy. The night before the boy's circumcision, people assemble in his home and song and dance takes all night long. This night long preparation is referred to as; khuminya. On this eve of circumcision several songs are performed. An example is the song entitled; mayi wo mwana (the boy's mother). In the song the soloist who mentions that the initiate resembles a fox; wanjusi; and a wild bird; ututu; both of which are culturally conceived by the Bukusu as ugly, employs dehumanizing satire. In this context, these allusions are meant to encourage and inspire the initiate to face circumcision bravely. The message interprets into meaning that the uncircumcised is bad and ugly; hence the boy should build 
courage to circumcise and abandon this undesirable status.

\section{Mayi wo mwana song:}

(I) Lubukusu version

\section{Soloist $\&$ response}

\begin{tabular}{|c|c|}
\hline$i$ & E mayi wo mwana bira olole- aah \\
\hline & $\begin{array}{l}\text { E mayi wo mwana bira olole- o mayi wo mwana bira } \\
\text { olole omwana }\end{array}$ \\
\hline & E papa wo mwana bira olole-aah \\
\hline & $\begin{array}{l}\text { Omwana wasuta chinyama- o mayi wo mwana bira } \\
\text { olole omwana }\end{array}$ \\
\hline & Omwana oyu afwana ututu-aah \\
\hline & $\begin{array}{l}\text { Omwana oyu afwana ututu- o mayi wo mwana bira } \\
\text { olole omwana }\end{array}$ \\
\hline & Omwana wasuta luliki-aah \\
\hline & $\begin{array}{l}\text { Omwana wasuta chinyama- o mayi wo mwana bira } \\
\text { olole omwana }\end{array}$ \\
\hline & Mayi wo mwana bira olole- aah \\
\hline & $\begin{array}{l}\text { Mayi wo mwana bira olole- o mayi wo mwana bira } \\
\text { olole omwana }\end{array}$ \\
\hline & E mayi wo mwana bira olole- aah \\
\hline & $\begin{array}{l}\text { E papa wo mwana bira olole- o mayi wo mwana bira } \\
\text { olole omwana }\end{array}$ \\
\hline
\end{tabular}

(II) English translation

\section{Soloist \& response}

\begin{tabular}{|c|c|}
\hline$i$. & Eh mother to the child come and see-aah \\
\hline$i i$. & $\begin{array}{l}\text { Eh mother to the child come and see- o mother to the } \\
\text { child come and see the child }\end{array}$ \\
\hline & Eh father to the child come and see- aah \\
\hline$i v$. & $\begin{array}{l}\text { The child has carried meat- o mother to the child come } \\
\text { and see the child }\end{array}$ \\
\hline$v$. & The child resembles ututu-aah \\
\hline$v i$. & $\begin{array}{l}\text { The child resembles ututu- o mother to the child come } \\
\text { and see the child }\end{array}$ \\
\hline & The child has carried luliki- aah \\
\hline ii. & $\begin{array}{l}\text { The child has carried meat- o mother to the child come } \\
\text { and see the child }\end{array}$ \\
\hline$i x$. & The child resembles fox- aah \\
\hline$x$. & $\begin{array}{l}\text { The child resembles a fox-o mother to the child come } \\
\text { and see the child }\end{array}$ \\
\hline & Eh the child's mother come and see- aah \\
\hline$i$ i. & Eh child's father come and see-o mother to the child \\
\hline
\end{tabular}

On circumcision eve, a bull is slaughtered, and food and alcohol brew; busaa are served all night to host the gathering that assembles for the event. The boy intermittedly jingles chinyimba amid song, trot and dance. All if not most of the invited relatives, friends, neighbours and guests including the father's bakoki assemble at the home of the boy by 7.00 p.m. on the eve of circumcision and they spend the whole night there, singing, dancing, feasting, drinking, chatting, planning the finalities to the event and cohesively waiting to witness the circumcision. This signifies social bonding. Very early in the morning, between $5.00 \mathrm{a} . \mathrm{m}$. and $7.00 \mathrm{a} . \mathrm{m}$. the boy is taken to the river to prepare him for the circumcision; khumana. During khuminya; most songs bear encouragement and advice to the boy. They also pass important advice to the entire community. Some songs encourage prescribed behaviour while candidly condemning proscribed behaviour. Some songs are vulgar and ridiculous while some serve as vent off in which people say the abominable including sexuality and socially stigmatized behaviour. Most songs pass historical and traditional vices of the community across generations as exemplified in; amba Mutalya (hold Mutalya) song:

\section{Amba Mutalya song:}

(I) Lubukusu version

\section{Soloist \& response}

i. E bali nekhwimbilisia bulai mutalya kuno khusuna mungaki nekhwilao- amba mutalya

ii. E bali enje chelechenje kumumu kufwa mulamwa kasenda engubo- amba mutalya

iii. E bali ututu bali ututu munyanga echo, munyanga echo khusuna mungaki nekhwilao- amba mutalya

iv. E bali nacha khusikulu sia chelebei nenja khukhesia nende wele- amba mutalya

v. Bali nekhwimbilisia busa mutalya kuno Baluyia bosi ne bengila-amba mutalya

vi. Bali nekhwembilisia busa mutalya kuno embalu yecha ya ndololwe- amba mutalya

vii. Bali nekhwembelesia lundi...ah webale oyee- amba mutalya

viii. Kuno mutalya kwe Baluyia... ah webale oyee- amba mutalya

ix. Embalu yecha ye Baluyia mu Kenya muno ndi Mango papa wakirera-amba mutalya

x. Bali mbukutu bali mbukutu munyanga echo ndi mango papa wakirera- amba mutalya

xi. Bali nalangilisia lundi nalanga bona khane nalanga nende omupofu-amba mutalya

xii. Bali nakhesia kwana kukhana kwanja khukhoma kuli kumpafu stiupiti khane Mango okubolele- amba mutalya

xiii. E kumpafu, stiupiti khane ukimwi eli munda- amba mutalya

xiv. Bali khwapima khutemperecha oli saa tano muchama kwabimba nelikosi-amba mutalya

xv. Bali ututu bali ututu munyanga echo khane ututu eli ne liloko- amba mutalya

xvi. Bali nekhwembelesia lundi...ah webale oyee- amba mutalya

xvii. Kuno mutalya nawe oloba...ah webale oyee- amba mutalya

xviii. E kuno mutalya kwe Baluyia-ah webale oyee amba mutalya

xix. $\quad$ Bali mbikita bali mbikita mumbikita bali mbikita munyanga echo omundu kecha nga Mango- amba mutalya

xx. Embalu yecha ye baluya munyanga chino ndi mango papa-amba mutalya wakirera 


\begin{tabular}{|c|c|}
\hline$x x i$. & $\begin{array}{l}\text { Bali mureberesia bulayi mutalya kuno, mutile lola, } \\
\text { mukhwese lola khane mutalya kwe sikhale- amba } \\
\text { mutalya }\end{array}$ \\
\hline xxii. & $\begin{array}{l}\text { Bali nalanga kwana kukhana kwanja khukhoma ndi } \\
\text { khane mawe okubolele- amba mutalya }\end{array}$ \\
\hline xxiii. & $\begin{array}{l}\text { Kuli kumpafu, stiupidi khane Ukimwi eli munda-amba } \\
\text { mutalya }\end{array}$ \\
\hline xxiv. & $\begin{array}{l}\text { Bali khwareberesia lundi khwareberesia khwalanga } \\
\text { mai wamwibula-amba mutalya }\end{array}$ \\
\hline$x x v$. & $\begin{array}{l}\text { Bali khwalangilisia lundi khwalangilisia khwalanga } \\
\text { mai wamwikhenya- amba mutalya }\end{array}$ \\
\hline$x x v i$. & $\begin{array}{l}\text { Bali khwalangilisia lundi khwalangilisia khwalanga } \\
\text { papa wa musuta-amba mutalya }\end{array}$ \\
\hline
\end{tabular}

(II) English translation

\section{Soloist \& response}

i. $\quad$ We sing well this Mutalya as we jump up and downhold mutalya

ii. It was in broad daylight that my sister in-law undressed herself-hold mutalya

iii. E, then on we have been jumping up and down-hold mutalya

iv. E, I went up to Chelebei hill to greet God-hold mutalya

v. E, we sing and sing again this mutalya for all the Luyia people to be circumcised-hold mutalya

vi. We sing and sing again this mutalya for the painful circumcision ritual is coming-hold mutalya

vii. So we sing again...ah we thank you-oyee- hold mutalya

viii. This is mutalya of the Luyia people... aah we thank you, oyee- hold mutalya

ix. Circumcision of the Luyia people in Kenya was founded by our father Mango- hold mutalya

x. It was Mango our father who brought circumcision in those days- hold mutalya

xi. I called and called only to discover I had called even the blind-hold mutalya

xii. I greeted a young girl, who insulted me; foolish, stupid; so it is Mango who taught her those words- hold mutalya

xiii. E, foolish, stupid, but she was carrying AIDS in her stomach-hold mutalya

xiv. We measured the temperature up to eleven o'clock then the guy started swelling his neck- hold mutalya

xv. They said that it was the ututu that had been used to perform witchcraft- hold mutalya

xvi. And we sing again, ah we thank you, oyee- hold Mutalya

xvii. You should know that this is mutalya-hold mutalya

xviii. Eh this is mutalya of the Baluyia, aah we thank you, oyee- hold mutalya

xix. In those days a man by the name Mango came- hold mutalya

xx. It is our father Mango who brought this practice of circumcision- hold mutalya

xxi. You ask well what this mutalya is, hold it, pull it, so the mutalya belongs to the ancestors- hold mutalya
xxii.
I called a young girl who started to insult me so she was sent by her mother- hold mutalya
xxiii. She insulted me, 'foolish', 'stupid' but AIDS was in her stomach- hold mutalya
xxiv. We found out who her mother was and called her- hold mutalya
xxv. We found out and called her mother who bore her in great pain- hold mutalya
xxvi. We again called the father who carried her- hold mutalya

The song; amba Mutalya, which overtly is "hold Mutalya", but covertly means 'uphold the tradition,' of the Bukusu community encourages the Bukusu to perpetuate the old circumcision tradition handed to them by Mango and other ancestors. The song also addresses the fact that HIV and AIDS is a reality in Babukusu community and people should be careful with their sexual behaviour and any risky associations with any person they come in contact with.

\section{Meanings and interpretations of experiences surrounding the circumcision cut}

Before circumcision, early in the morning, the boy is taken to the riverside, where khumana happens. Khumana also referred to as; khulonga involves the boy being escorted to the riverside and to a special point where he is smeared; actually molded in chilling cold dark grey riverside mud, all over his body. The person who does this is a specially selected circumcised man; omumani; of high morals, respect and regard and a relative to the boy, from either paternal or maternal lineage (preferably an uncle), who underwent a successful circumcision and who is reproductive or potentially reproductive. This adds a lesson to the boy and community calling for integrity, social responsibility and for the reproductive role as epitomized by omumani role model. The place where khulonga happens is a sacred place referred to as; sitabicha. Once the molding is done, a small protuberant knob of the same clay is placed on the top of the boy's head. On it is planted a special grass stick straight up in the sky. This uprightness is reminiscence and thus symbolic of the straight, bold and courageous bravery the enigmatic Mango faced the serpent; Yabebe with and hence what circumcision signifies, thereof. Molded, in a decorative way, the stark naked boy is led home by a huge charged crowd chanting sioyaye song, intermitted by serene silence devoid of the rowdiness of the crowd and the jingling of chinyimba; sure, something special is about to happen! The rationale behind khumana at down, minutes to the cut is indeed to provide numbness to the body and hence some form of anaesthesia in readiness for the cut. Traditional Babukusu circumcisions are done without any form of clinical anesthesia because it is supposed to be painful enough to prove courage. The boy who is almost dazed and facing straight up is led to the circumcision spot; etyangi for the cut. The boy is met outside the homestead by the circumciser's assistant and the father who quickly leads him to the specially marked spot 
right outside the mother's house for the traditional surgical cut; embalu.

As everybody goes dead silent, the boy stands bravely facing the sky and within ten seconds, he is circumcised. He either stands akimbo or holds a stick on the shoulder and faces up. The circumciser blows his whistle to signify a successful circumcision and the crowd goes in ululation and in jubilation and praise song and dance especially chanting; khwera omurwa song. The song is performed immediately after circumcision and it stresses the fact that the Babukusu have a reason to celebrate for having killed one of their perennial enemies, Omurwa, a singular form of Barwa. Barwa (the Sabaot, Kalenjin) are highland Nilotes who live on the slopes of Mount Elgon, and they from time immemorial, clash with the Babukusu over livestock and land ownership matters. It is ironical that the song is about killing the same people; Barwa from whom Babukusu trace the myth of their own circumcision. However, in this case, circumcision is compared to the hard task of fighting and defeating a strong or dangerous enemy and the joy that one feels or achieves after defeating such an adversary. Therefore, the song means success and achievement over a hard obstacle.

\section{Khwera omurwa song:}

(I) Lubukusu version

\section{Soloist \& response}

$\begin{aligned} & \text { i. } \text { Yaya khwera omurwa- aah khwera omurwa } \\ & \text { ii. } \text { Khwera omurwa yaya khwera omurwa- aah khwera } \\ & \text { omurwa } \\ & \text { iii. } \text { Khwera omurwa papa khwera omurwa- aah khwera } \\ & \text { omurwa } \text { Khwera omurwa sande khwera omurwa- aah } \\ & \text { iv. } \text { Khwera omurwa } \\ & \text { k. } \text { khwera omurwa chuma khwera omurwa- aah }\end{aligned}$

(II) English translation

\section{Soloist \& response}

i. My brother we have killed omurwa- aah we have killed omurwa

ii. We have killed omurwa; my brother we have killed omurwa- aah we have killed omurwa

iii. We have killed omurwa; my father we have killed omurwa- aah we have killed omurwa

iv. We have killed omurwa; my age group we have killed omurwa- aah we have killed omurwa

v. We have killed omurwa; my chuma age group we have killed omurwa- aah we have killed omurwa

The crowd then rewards the boy for his bravery to withstand the knife, with all sorts of gifts; commonly money. The mother presents a tray of samples of foodstuffs that the community commonly grows; bibialila with a star grass ring to symbolize wish for prosperity for the boy in his transformation into a new adult life. The boy is then escorted by father to the special hut where he will stay as he heals; likombe. The boy is first taken around the mother's house and enters the house backwards, while facing out. Going around the house symbolizes that the boy is cutting dependence link with the mother now that he is mature and independent and henceforth, he starts to interact with the mother in a special and respectable way. For example, he can no longer enter the mother's bedroom. Entering the house backwards means he will be in the house only temporarily as he heals and get to his own house upon healing and graduation, signifying transition.

\section{Lubaka}

On the circumcision day, and soon after the circumcision, the father of the circumcised boy is mandated to give a special and reciprocal reward to his circumcision age set members; bakoki. This special reward is referred to as; lubaka. It is given as money, ranging from Ksh. 50 and above, to each bakoki that presents themselves on the occasion, depending on how the recipient is valued, and on the reciprocal benefit gained earlier or in anticipation when their turn reaches to circumcise a son. It can also be given in terms of beef meat, and if well endowed the host can provide bakoki a bull that they slaughter on the spot and share out the meat. The age set members are a special group on this occasion, and they are given a high-table regard, reception and treat. When you give to or receive lubaka from one member, you must receive or give back almost in equal amounts and pomp when your turn comes to circumcise or attend a circumcision in such a capacity. It is a strictly reciprocal exchange affair that perpetuates age set identity, solidarity among peers, and bondage and wealth exchange across members of Babukusu community.

\section{Post-circumcision events and their interpretation \\ Lubito}

This ceremony involves passing of messages to the initiated young man as they heal. A special alcohol brew called; kekamatasi is made and drank to congratulate the circumcised and as signal that the boy can now receive people and their advice hence preparing him for adulthood. This is done in front of a somber family led by elders and the father to the circumcised boy, including the mother, and the message is passed by the circumciser who keeps sipping on the brew gaggling it and spitting it on the boy and repeatedly stroking his head with the very lukembe that circumcised him. The circumciser passes advice messages to the boy often using symbols and symbolic meanings to pass hidden messages:

"I circumcised you using this lukembe. It will never cut you again in your life and I want you to be a straight forward man in your life. I want you to reproduce children. I want you to respect your age mates and people older than you in your community and in the world. If you seduce a woman, I want you to seduce and have sex with people of your age and not older and married women. "Kumuliango kumwikule kukwoo ne kumwikale kwa bene"- an open door 
is yours and a closed door belongs to someone else" Simiyu.

Along with the prescriptive messages above, the boy is also given proscriptive messages. The phrase "Kumuliango kumwikule kukwoo ne kumwikale kwa bene" (an open door is yours and a closed door belongs to someone else)", is a key reproductive message passed to newly circumcised Babukusu boys. It interprets to mean that the boy is now sanctioned to have sex since they are adults, as marked by the circumcision. This message is commonly passed to boys circumcised traditionally and it ushers in permission for the boy to undertake their reproductive role. It is important to note that the message also cautions the boy that they must carefully choose their sex and reproductive partner by avoiding women who are attached to or married to someone else. The young man is also advised about tasks they are expected to perform in life as mature men. In addition the initiators display and introduce symbolic use and significance of some farm tools and material to be used by the initiate in his future life:

Case narrative by researcher: the tools observed included: Spear; explained as a defense instrument for use to protect the boy and his family against enemies and to be used for fighting the enemy if aggressed or attacked. Panga (machete); to use for clearing farm bush for farming, keeping the homestead hedge trimmed, for use in cutting posts for construction and never to use the panga for fighting. Jembe (hoe); presented as a tool for farming especially for digging and weeding. Pen; represents the spear in contemporary life of Babukusu. You can fight by using the pen through writing and gaining knowledge. Book; the book represents the shield against illiteracy and ignorance, contemporarily. It should be used to "protect the boy from the enemy". It is to encourage him to read hard so that to handle the difficulties in life, smoothly. Additional messages include how to behave as a mature person. To respect sex and not to have sex with all women they meet as a respect measure in society and in caution against HIV and AIDS today. Further on, the boy is told to be hardworking and rear animals such as chicken, goats, sheep and cattle. To farm and plant all crops found in the community. The young man is asked to show respect to all people both young and aged, to avoid drunkenness and to work very hard in class and excel in life. The boy is cautioned, not to get involved in kitchen affairs since these are affairs of their would-be wife. They are cautioned never to venture in the mother's sleeping place; meaning to respect privacy of the mother and father. Further to this, they are cautioned against bewitching or causing any form of evil to any fellow human being. They are advised to be contented with what they work for and possess, and their status in society and never to use force to get what is not rightfully theirs.

Lastly, the boy is stunningly told that if they engage in what is proscribed or do not do what is prescribed by society, they will suffer ills and fail to prosper in their life. There are some additional processes that accompany lubito, but which are distinct in their way and to particular
Babukusu clans and groups. For example, khutwikha is a process that is associated with lubito, and which is about naming ceremony by means of which the circumcised boy is given a traditional name belonging to one of the heroic ancestors or fore fathers. The new name signifies rebirth, but also reincarnation into a role model to the rest of society members.

\section{Khukhwalukha (birth or hatch)}

On the eve of khukhwalukha; which means birth or graduation to a higher level, the circumcised boys spend the night out of their homes as a group, undergoing ceremonial rite referred to as; khurura, literally meaning "to go out". In the evening of the graduation eve, the young men go to spend out in the "wilderness" and come back the next day to graduate, as described next:

Case narrative by researcher: during this occasion, the boys test out their anticipated roles in manhood including: bravery, courage, and skill of house construction. They spend the night by bonfire chatting about their own heroic experiences of circumcision and their future expectations. This marks end to the limbo state of wound healing, referred to as; bufulu. While in bufulu state, omufulu (the initiate), is somewhat secluded and restricted from the usual day to day activities notable among which is, child play, association with women and even sex. His movement is restricted and confined to his healing hut or room. His diet is also proscriptive, restricting to select foodstuff such as milk, egg, fish, potatoes, meat and ugali (a staple solid maize flour meal), among other foods. However, during khurula, the boy is set free. The occasion thus marks the end to childhood and it ushers in graduation to adulthood, the next day.

In traditional circumcision set up, khurula takes place in various out-posts including a bush, banana plantation, rocky area and even an isolated building together as a group of initiates preparing to graduate the next day. Yet those circumcised through the Church initiative spend their night praying as a group at Church and they also graduate the next day.

Khukhwalukha is the ceremony marking graduation of the newly initiated. It is the ceremony marking healing of the circumcision wounds and the ceremony that ushers in a newly circumcised young man. It is climax to initiation ceremony, ushering in adult life and manhood, and indeed a conclusion to the circumcision process. Therefore, this process is important to young men circumcised both clinically and traditionally. In the morning, the boys get to the river under guidance of the already circumcised, they bathe, clean, shave, dress in new clothes and are led home singing the song; lelo endia mundubi embya, meaning, 'from today I will eat from my own new plate, I am independent'. In Babukusu community, it is customary for young boys who have not yet undergone circumcision to eat together from the same plate. However, once one gets circumcised, he is served with food in his own plate. Therefore, he is respected by his community members and 
becomes independent in his thoughts and deeds. This is the last song performed in Babukusu circumcision ceremony. It is joyfully performed by the initiate in conjunction with his younger brothers and sisters during his pass out ceremony that is always held in the month of December, four months after circumcision cut, during every circumcision year.

\section{Mundubi embya song:}

(I) Lubukusu version

\section{Soloist \& response}

$\begin{array}{cl}i . & \text { Oh, Lelo!- lelo endia mundubi embya } \\ \text { ii. } & \text { Mayi walomanga- lelo endia mundubi embya } \\ \text { iii. } & \text { Papa walomanga- lelo endia mundubi embya } \\ \text { iv. } & \text { Senge walomanga- lelo endia mundubi embya } \\ \text { v. } & \text { Kukhu walomanga- lelo endia mundubi embya } \\ \text { vi. } & \text { Oh, Lelo!- lelo endia mundubi embya }\end{array}$

(II) English translation

\section{Soloist \& response}

$\begin{aligned} \text { i. } & \text { Oh, today!- today I am independent } \\ \text { ii. } & \text { Mother did not respect me-today I am independent } \\ \text { iii. } & \text { Father did not respect me-today I am independent } \\ \text { iv. } & \text { Auntie did not respect me-today I am independent } \\ v . & \text { Grandmother did not respect me-today I am } \\ & \text { independent } \\ \text { vi. } & \text { Oh, today!- today I am independent }\end{aligned}$

Once they are led back home, on graduation day, the boy's father spearheads advice passed to his graduating son. Other participants include uncle and grandfather and priest by prayer especially for clinical circumcisions. The process goes this way:

Case narrative by researcher: the mother to the boy prepares bananas and potatoes then she lays them on a traditional tray; lutelu, she covers them with banana leaves and puts them outside the house. On arrival at home, the boy, and his four peers and young helper (on this occasion), go straight to lutelu and start eating the food. After a while they start throwing and playing around with the remains of the meal. Eating together is a sign of unity but the intentional playing with food is portray of the last childhood play, since soon after, the boy shall graduate from childhood to an adult. Next, the father (this is also done by the uncle or a selected elder), holding a club; elungu, authoritatively calls the boy and stands facing him. He orders him to remove the shorts he is wearing and the father dresses him in new pants, trousers, shirt and shoes (from a short to a trouser means growth into adulthood). Next, the father starts talking to the boy authoritatively: “...from today onwards you are an adult. Wefwalile engubo yase (you have worn my own cloth- meaning you are an adult man just like me), and by so doing you must respect the elderly. Any person of my age call him father and any person of your mother's age call her mother. Any person aged above me call them grandfather or grandmother. Never play with somebody's wife since you will be penalized; - if caught you pay siluhi; a penalty fine of a cattle. Never have sex with an animal; sisyayo (this is taboo), and you should take care since these days there is AIDS. When you are ready to get married you should ask the woman her name, her clan, and make sure she is not your relative first (endogamy is taboo). You must thereafter, take care of the wife and make her a good and beautiful woman, and most important bear children with her. You should always be cautious with strangers since they can be your enemy". The father finally gives the boy a spear and tells him; "...this is what we used to fight our enemies with in the past but for now we fight with the pen, therefore, I want you to work hard in class and in your education". The father further asks the boy to demonstrate how to kill the enemy. The boy obliges by throwing the spear accurately enough (as practiced overnight) so as it pierces and sticks in the ground as he shouts nerire omurwa (I have killed the enemy). Next the boy is led into the house and welcome to the special meal made for him. At this time all visitors are welcome to the feast marking the end of the circumcision rite.

Further advice often referred to as khukambila, is made to the boy. Those in the gathering, who have brought with them presents, hand them over to the smart, neatly dressed and clean shaven boy who on this occasion is quite happy and proud of his achievement. Rewards in terms of money and chicken continue days after, as the boy visits his relatives to acknowledge their support and as he reemphasizes his achievement. This process is called; khubachukha, and it takes about ten days during which the young man is referred to as; Omutembete- the newly graduated. Eventually, the boy has transited through four prime circumcision stages explained as follows; Omusindeuncircumcised; Omufulu- the circumcised as they heal; Omutembete- the graduated; Omusani- the young circumcised adult man. As a result omusani is the desired circumcision outcome; an adult who belongs, identifies and associates with a particular circumcision age set; thus circumcision is the making of (the) Babukusu man.

\section{Babukusu male circumcision age sets}

Since its mythical origin and much with time, Babukusu circumcision has developed into a more periodic and systematic categorization defined by age sets. Babukusu circumcision age set is referred to as; sikhebo. There has developed a legacy and structure where men who circumcise the same period belong to one such age set. Amongst Babukusu, circumcisions are carried out during the month of August, when community realizes harvests of their staple food crops including maize and beans. Recently, and in a much more consistent manner, circumcisions have been occurring on even number years, meaning a lapse of one year in between circumcisions. Though the inception of this structure is conjectural, there are nuances that one circumcision set encapsulates men circumcised within about ten years, taking in five or so consecutive circumcisions before there is shift to the next one. Table 1 below shows eight Babukusu circumcision age sets together with those of other circumcising sub ethnics they neighbour; the Tiriki, 
the Nandi and the Pokot who also practice circumcision of their males:

Table 1. Circumcision age sets across Babukusu, the Tiriki of the Luhya ethnic group and the Nandi and Pokot of the Kalenjin ethnic group

\begin{tabular}{cccc}
\hline Babukusu & Tiriki & Nandi & Pokot \\
\hline Kolongolo & Golongolo & Korongoro & Korongoro \\
Kikwameti & & Kipkoimet & Kipkoimet \\
Kananachi & Kabalach & Kaplelach & \\
Kinyikeu/ & Jiminigayi & Kipnyikeu & Kipnyiken \\
Kinyikewi & Nyonje & Nyongi & Nyongi \\
Nyange & Maina/ & Maina \\
Maina & Mayina & Mainek & Chumo \\
Chuma & Juma & Chumo & Sawe \\
\hline Sawa & Sawe & Sawe &
\end{tabular}

Change from one circumcision age set to the other is determined by death. When the last living man of the oldest existing circumcision set dies, the elders who are the custodian of this structure, name the next circumcision a new set. Since this systemization started, circumcisions and people that belong to each, have been chronologically categorized as follows; Kolongolo (dating back in the $19^{\text {th }}$ century); Kikwameti (early $20^{\text {th }}$ century); Kananachi (1920s - 1934); Kinyikeu (1936 - 1946), Nyange (1948 - 1958), Maina (1960 - 1970), Chuma (1972 - 1986) and currently Sawa (1988 - to date). A boy circumcised in the year 2004, our reference point, is referred to as; Omusawa and their set came to calling when the last living; Omukolongolo died. With this stratification in place, age grades function to stratify society along normative roles, responsibilities and functions. A member of a set generally is a head of household, a producer for subsistence, a military and defender of household and community and they are heir and custodian to property and wealth. Because wives belong to same age sets as their husbands, females are also governed in behaviour and interaction by this social structure stratification and differentiation.

\section{Discussion}

\section{Symbolic messaging and rationale in male circumcision}

The importance of ethnography of circumcision is emphasised by this paper, pitching on meanings and rationale of circumcision messages. Babukusu male circumcision procedure is one type amongst the many ways around the world by which males circumcise. Both traditional and clinical circumcisions are one set of procedures of male circumcisions worldwide, WHO, UNAIDS, JHPIEGO ${ }^{[25]}$. Babukusu observe adolescent male circumcision of boys at early and mid teenage. Despite the difference in procedure, similarity between traditional and clinical circumcision here lies in the role and function they both play; initiating boys into adulthood just like most adolescent male circumcisions in Sub-Sahara Africa, Zoske $^{[26]}$, Brown ${ }^{[27]}$, Barker and Ricardo ${ }^{[28]}$, UNAIDS ${ }^{[29]}$, UNAIDS/CAPRISA ${ }^{[4]}$. Babukusu traditional circumcision has three phases embellished with initiation messages that speak to the meaning and rationale of male circumcision, garnished in symbolism and song. The supposition of this paper largely agree with previous works by the authors that male circumcision is arbiter of transition between childhood and adulthood, Egesah ${ }^{[23]}$, Wanyama ${ }^{[3]}$. The significance of circumcision messages are found in meanings of identity, sense of community, solidarity, production and reproduction. Babukusu mark and recognize their identity, norms, expectations, values, common cognition and worldview through male circumcision, since these key phenomena construct the core of initiation. By these means, Babukusu have managed to perpetuate their traditions and customs and thus their entire cultural structure from one generation to the other as marked and facilitated by initiation through circumcision.

The one week practice period prior to circumcision prepares the boy for core events and process of circumcision and it offers stage for the boy to build courage and make a final commitment to circumcise. A sense of community is attained when initiates invite kin of all walks of life to participate and witness their circumcision. Relatives who come to witness a circumcision bring with them rewards and material benefits to the boy and parents who host the circumcision and to cement solidarity, Babukusu apply a generalised reciprocity through age-set exchanges of wealth during circumcision through lubaka from bakoki. Khumana and the logic of circumcising in chilling morning conditions can be explained as conditions that enable some form of anaesthesia to the boy and a way to steel them in readiness for the cut, although from a layman's position this can be seen as unhygienic and torturous. Omumani is selected carefully and they are chosen from persons of high integrity and morals, thus symbolically asking the initiates to emulate community recognised role models, and this emphasizes the importance attributed to this rite of passage. During circumcisions, different people engage in different roles and functions which are selective and definitive. These roles and functions are meaningful, since they enable events to take place successfully. Here for example, community finds a chance once in two years to bring out aspects of society that are considered taboo in normal day to day life. Songs can be vulgar and with themes that mock and ridicule the ills of society openly without people questioning. Songs can address incest, extraneous sex, rape, paedophilia, divorce, theft, meanness and other social ills. Further, circumcision song and dance portrays and enhances Babukusu tradition and culture in general terms. Babukusu circumcision thus, carries superfluous and heavier weight more than what we can realize from observing events at surface. The importance of Babukusu circumcision is therefore, not only the symbolic surgical cut but there is covert meaning that defines people and what community expects out of them in 
life. Notwithstanding, the rite is optimal in transmitting normative messages and lessons across generations through the initiates and their peer age sets. Lubito and khukambila constitute the core of initiation messages that are meaningful and rational in prospect. This is why messages contained therein are both prescriptive and proscriptive along community expectations. For example, they address both productive and reproductive roles that are inevitable in adult life. The message; "Kumuliango kumwikule kukwoo ne kumwikale kwa bene" (an open door is yours and a closed door belongs to someone else)", can imply "go ahead and exploit sex", proposes sex and reproductive life expectation to the young adult, but in the same breadth it cautions against reckless and tabooed sex and sexual risks such as HIV and AIDS and pre-marital sex associated with unwanted pregnancy. Today, the circumcision forum especially khukhwalukha and the wound healing period, can be an opportunity window through which impressionable education and skills in family education, health and entrepreneurship among other real time topical issues can be imparted to the youth, to keep the circumcision process relevant to times.

\section{Conclusions}

Circumcision events and processes adorned in symbolic messaging and rationale are meaningful and significant since they lead to the ultimate goal of initiating the circumcised into adult roles and expectations; "making the man". Babukusu circumcision song and talk messages together with skill lessons are symbolized to hide actual covert meanings that they portray. This paper presents how the ethnographer interprets and reveals to the reader, underlying meanings of these elaborate circumcision events, processes, experiences and messages that signify male circumcision. The paper therefore, contributes to an understanding of meanings of people's experiences and why we do the things we do in a particular manner. The paper builds and enhances ethnography and ethno-music of male circumcision from a meaning centered approach, and the reader and sub-Sahara male circumcision enthusiasts are able to see what underlies beneath a detail of male circumcision ethnography and ethno-music.

\section{REFERENCES}

[1] Columbia Encyclopaedia (2004). Sixth Edition.

[2] Government of Kenya-G.O.K-MOH (2007). Policy on male circumcision in Kenya. Nairobi: Government printer.

[3] Wanyama, M.N. (2009). Form and content of African music: a case study of Bukusu circumcision music. Saarbrücken: VDM Verlag.
[4] UNAIDS/CAPRISA (2007). Social science perspectives on male circumcision for HIV prevention: summary report, of the Durban meeting. Geneva, UNAIDS.

[5] Marck, J. (1997). Aspects of male circumcision in subEquatorial African culture history: Health Transition Review, Vol. 7: 337-359.

[6] Van Gennep, A. (1960). Rites of passage. Chicago: University of Chicago Press.

[7] Wagner, G. (1949). The Bantu of North Kavirondo. London: International African Institute.

[8] Hammersley, M. (1992). The generalisability of ethnography: what's wrong with ethnography? London, Routledge.

[9] McCall, M. and Simmons P. (1969). Analytical descriptions in theory. New York, Albin Press.

[10] Geertz, C. (1988). Works and lines: the anthropologist as another. New York, PTR.

[11] Sorre, M. B. (2005). Insider-outsider debates in the construction of ethnography: Maarifa; Journal of Humanities and Social Sciences, Vol. 1. 1: 19-25.

[12] Levi-Strauss, C. (1987). Exchange and network theories. New York, McGraw Hill.

[13] Znanieki, P. (1992). "Ethnography as a theory". In what is wrong with ethnography? Hammersley, M. (ed) pp. 60-64. London, Routledge.

[14] Osogo, J. (1966). A History of the Baluyia. Nairobi: Oxford University Press.

[15] Were, G. S. (1967). Peoples of East Africa: a history of the Abaluyia of western Kenya. Nairobi: East Africa Publishing House.

[16] Makila, F.E. (1978). An outline history of Babukusu of western Kenya. Nairobi: Kenya Literature Bureau.

[17] Wandibba, S. (ed), (1985). History and culture in western Kenya: a people of Bungoma District through time. Nairobi: Gideon Were Press.

[18] Government of Kenya-G.O.K-MPND (2002). Bungoma district development plan 2002-08. Nairobi: Government Printer.

[19] Government of Kenya-G.O.K-MPND (2010). Bungoma district development plan 2005-10. Nairobi: Government Printer.

[20] Government of Kenya-G.O.K (2012). Kenya (Bungoma) County fact sheets. Nairobi: Government Printer.

[21] Government of Kenya-G.O.K (2012). Kenya development indicators. Nairobi: Government Printer.

[22] Bailey, R.C. and Egesah, O.B. (2006). Assessment of clinical and traditional male circumcision services in Bungoma district, Kenya: Complication rates and operational needs: Special Report of PSI, AIDSMark and USAID.

[23] Egesah, O.B. (2009). Male circumcision in Africa: ethnographic evidence from the Bukusu, Kenya. Saarbrücken: VDM Verlag. 
[24] Katam, C.T. (1996). The influence of circumcision on academic achievement and self-concept: a case study of West Pokot district, Kenya. MA Thesis, Moi University, Kenya.

[25] WHO/UNAIDS/JHPIEGO (2006). Manual of male circumcision under local anaesthesia: paper version 2.2. Geneva, WHO.

[26] Zoske, J. (1998). Male circumcision: a gender perspective: The Journal of Men's Studies, Vol. 6. 2: 189-208.

[27] Brown, J.E., Micheni, K.D. Grant, E.M. Mwenda, J.M. and Muthiri, F.M. (2001). Varieties of male circumcision: a study from Kenya: Sexually Transmitted Diseases, Vol. 28: 608-612.

[28] Barker, G. and Ricardo, C. (2005). Young men and the construction of masculinity in sub-Saharan Africa: implications for HIV/AIDS, conflict, and violence. Social Development Papers: Conflict Prevention and Reconstruction (CPR Paper no. 26). Washington, World Bank.

[29] UNAIDS (2006). Collaborating with traditional healers for HIV prevention and care in sub-Saharan Africa: suggestions for programme managers and field workers- best practice collection. Geneva, UNAIDS. 